\title{
Assessing Men and Maids: The Female Servant Tax and Meanings of Productive Labour in Late-Eighteenth-Century Britain
}

\author{
Susan E. Brown
}

\section{I}

This essay takes as its focus the debate surrounding an especially contentious economic policy of the late eighteenth century: the tax on female domestic servants. A study of the motivations behind, and public responses to taxes on purported luxury items provides an opportunity to gauge popular understandings of luxury, of productive and unproductive labour, and the assumptions regarding gender implicit in these notions. The controversy surrounding the female servant tax offers a new perspective on historical accounts of the feminisation of domestic service, in terms of how the labour of domestic service was imagined and validated. ${ }^{1}$ Once ignited, the debate spread far beyond the immediate concerns of servants and their employers to encompass a wide sweep of interrelated social and moral issues. A complex weave of apprehensions and assumptions underlay and gave shape to the controversy. Public commentary generated by the proposed maidservant tax offers insight into contemporary attitudes regarding the appropriate roles of men and women in the marketplace and in the home, the proper functioning of the household economy, and widespread anxieties concerning masculinity, effeminacy, and national degeneration. Crucially, the vociferous protest against taxing female servants as items of luxury expenditure reveals fundamental differences between fiscal policy and its underpinning economic philosophy on the one hand, and popular understandings of domestic service and the meanings of work, on the other.

Participants on all sides of this debate set their arguments within a conceptual framework provided by Enlightenment economists. The works of theorists such as Adam Smith, Sir James Steuart, Adam Ferguson and David Hume were accessible to both government ministers and the public, frequently cited in the press and "translated" for popular consumption. Although a shared language of political economy is evident in this controversy, an analysis which characterizes this discourse in terms of a straightforward and gradual diffusion of the theories of political economists outwards and downwards to a wider public would overlook much of the complexity of the cross-cultural process at work. A range of cultures and modes of representation present themselves in this controversy, encompassing the intellectual milieu of economic philosophers, the fiscal policies and legislative procedures of government as well as a culture of public debate, expressed in newspapers, pamphlets, 
coffeehouse and tavern debates, and the medium of satirical prints. This essay is intended to be more than an exercise in charting the influence of political economists on government ministers and the public. Rather, it seeks to uncover what government and the public made of these concepts. The cross-cultural dynamic evident in the dispute over the maidservant tax was not a passive one but very much an active mode of adapting, transforming and frequently challenging the notions articulated by intellectual and legislative elites.

Embedded within this economic discourse was a set of interrelated assumptions regarding gender roles, assumptions which were brought to the fore over the course of the debate on the maidservant tax. While these notions may have received particular emphasis during the controversy, they were nonetheless a central feature of the economic thought of the period. ${ }^{2}$ Critiques of both neo-classical and Marxian economic traditions have highlighted the limitations of analyses that ignore women and families and neglect the economic value of household work. The gendered construction of economic thought has proven to be a fertile subject area for contemporary economists and continues to be the subject of historical analysis. ${ }^{3}$ Through a study of the use and popular understanding of terms such as luxury, productive labour and industry this essay offers further historical grounding to the ongoing investigation into the central role played by gender in the formulation of economic models.

\section{II}

Prime Minister William Pitt introduced the tax on female servants in 1785 as part of a package of measures designed to offset the mounting debt incurred by the recent disastrous war with America. Pitt's budget proposals continued a pattern of funding wars through taxes that fell disproportionately upon the households of the middling and labouring classes. Although Pitt's predecessor Lord North claimed that government taxation measures were guided by the principle that "luxuries ought to be taxed ... because the first weight ought to fall upon the rich and opulent," in reality government revenues were increasingly drawn from customs and excise duties on articles of mass consumption. ${ }^{4}$ As the Treasury sought to extend the range of taxable commodities, the definition of "luxury" was stretched to the limits of plausibility.

Included in Pitt's latest round of imposts was a tax on retail shops and higher rates for the existing levy on male servants. A tax on menservants had been on the statute books since 1777 (to be paid by their employers) and was limited to those servants who bore a direct relation to the luxuries of life- - butlers, coachmen, stable-hands, gamekeepers - as opposed to those employed in agriculture, husbandry or as apprentices in manufacturing. For the most part the legislation enshrined a particular set of assumptions regarding distinctions between productive labour and conspicuous consumption, necessary work and idle luxury, the realm of business and the realm of the home. The scale of taxation was progres- 
sive, rising from $£, 1-5 \mathrm{~s}$. for one manservant to $£ 3$ each for the employers of eleven and upwards. Female servants were taxed at a lower rate, starting at 2 s. $6 \mathrm{~d}$. for a single servant and rising to 10 s. each for those employing three or more maidservants. ${ }^{5}$ Taxing the employers of menservants was justified in Pitt's view as "the servants which they kept were more for vanity than real use, more for luxury than for actual service, the tax would be more a tax upon unnecessary extravagance, than upon industry or servitude."

The proliferation of taxes on luxury consumption items in the late eighteenth century may be viewed, in part, as the legislative manifestation of an ambivalent attitude towards luxury encountered amongst the public at large, as well as in the works of economic theorists. ${ }^{7}$ David Hume's observation that "Luxury is a word of an uncertain signification, and may be taken in a good as well as in a bad sense," not only indicated the impossibility of defining luxury in absolute terms, but also suggested the potential for public benefit inherent in private expenditure on luxury goods. ${ }^{8}$ Hume, together with Adam Ferguson and Adam Smith conceded the difficulties faced by philosophers and government ministers alike in their attempts to differentiate luxuries from necessities, pointing out that any definition would need to take into account variations of time, place and social rank. Ferguson's remark that "The necessary of life is a vague and relative term: it is one thing in the opinion of the savage; another in that of the polished citizen," was reiterated by Smith in a now familiar passage in which he defined necessaries as "whatever the custom of the country renders it indecent for creditable people, even of the lowest order, to be without," citing the examples of linen shirts and leather shoes. ${ }^{9}$ Both Hume and Sir James Steuart sought to distinguish innocent forms of luxury from pernicious excess in order to counter the depiction of luxury as a malignant force in civil society, debauching and effeminising a nation's citizens and diminishing their capacity to defend their country. ${ }^{10}$ Awareness of the corrupting potential of luxury co-existed with a recognition of its role in providing employment for the masses. It was this positive side of the coin of luxury which Steuart emphasized in his own definition of the term: "the providing of superfluities, in favour of a consumption, which necessarily must produce the good effects of giving employment and bread to the industrious." 11

The benefits of luxury expenditure were felt not only by the industrious labourer, but also by the Treasury office. Here, in the assessment records and revenue calculations of clerks and tax commissioners we find a concrete manifestation of Mandeville's notion of luxury as both private vice and public benefit. In the never-ending search for sources of state revenue, government ministers increasingly looked to the consumption patterns of the upper and middle classes as a means of filling the state coffers. By the end of the eighteenth century the list of luxury items subject to taxation was extended to include carriages, horses, dogs, clocks and watches, in addition to household servants. Although the government's taxation policies were the focus of a sustained campaign of public protest, 
this form of revenue generation was regarded as far less objectionable than an income tax, a measure which, in the words of Adam Smith, would require "an inquisition into every man's private circumstances," an intrusion of central government "altogether insupportable in a free country." 12 Enlightenment economists favoured taxes on luxury items, as both efficient revenue generators and convenient for taxpayers, who were free to refrain from making such superfluous purchases if they so desired. ${ }^{13}$

Pitt's choice of objects of taxation is striking in light of the views of these economic commentators, particularly given his well-known admiration for the work of Adam Smith. As a highly pragmatic politician, it is unlikely that Pitt's specific policies sprang directly from the pages of the Wealth of Nations, but the direction of his policies was no doubt shaped by his enlightened education. As a young man Pitt studied Smith's economic philosophy, pronouncing it "the best solution to every question connected with the history of commerce or with the systems of political economy."14 Government ministers, seeking to win support for what they knew would be unpopular fiscal measures, frequently cited the views of economic theorists as a means of providing a degree of intellectual credibility for their proposals. Such a strategy ran the risk of alienating the public, with whom "ingenious theories" carried little weight when balanced against the day-to-day realities of the household and marketplace. ${ }^{15}$ As we shall see, this was the case with the public response to the tax on female servants, a policy which provoked the articulation of alternative definitions of "usefulness," "necessity," and "productive labour."

Pitt's division of servants into those who were kept for real use and those kept for mere vanity echoes Smith's categories of productive and unproductive labour-that which adds value to an object, which realizes itself in an exchangeable commodity and that which does not. ${ }^{16}$ While Smith insisted that unproductive labourers such as churchmen, attorneys and physicians might provide society with valuable services, the term "unproductive" does take on a pejorative meaning in the Wealth of Nations. ${ }^{17}$ Smith observed that "the idleness of the greater part of the people who are maintained by the expense of revenue [i.e., unproductive labour] corrupts the industry of those who ought to be maintained by the employment of capital [i.e., productive labour]." ${ }^{18}$ Smith's concern was not just for the morals of unproductive labourers but also for the overall health of a nation's economy. He compared the revenue spent by a rich man only to be consumed by idle guests and menial servants, to that spent as capital directly employing productive labour. He expressed a clear preference for the cycle initiated by that form of expenditure, which employs productive labour and consequently increases the exchangeable value of a country's annual produce and its real wealth. ${ }^{19}$

\section{III}

The distinction between productive and unproductive labour, and the increasing association of "work" with the creation of wealth evident in the writings of eigh- 
teenth-century political economists had significant implications for contemporaries' understanding of the work of men and women. ${ }^{20}$ Taking the servant tax as an example of an economic policy resting on the distinction between productive and unproductive labour, necessary and luxury expenditure, it is possible to draw out these implications with greater clarity. An initial reading of the legislation would appear to suggest that unproductive labour was defined similarly for both men and women; that is, any male or female servant not employed for the purposes of husbandry, farming, dairy or manufacture. However, the notion of "unproductive" differed subtly in its application to the work of men and that of women, differences which became clearer in the ensuing public debate.

In the new legislation the unproductive labour of male servants was carefully defined; altogether over two dozen distinct occupations were listed as liable to taxation. Steedman notes that one of the most significant aspects of the new taxes on menservants was their emphasis on what a servant did in the workplace as key determinants of their status, in contrast to legal manuals which defined service in terms of residence in a household and contractual terms between masters and servants. ${ }^{21}$ In general the act was intended to encompass those positions associated with the conspicuous consumption of the aristocracy-valets, butlers, coachmen, footmen, gamekeepers, confectioners-but also included men employed as waiters in taverns, coffeehouses and inns. By contrast, no such careful delineation of what might be considered unproductive labour with regard to female servants was considered necessary. The act simply stated that all employers of female servants were liable to taxation, indicative of an attitude towards female domestic labour as unspecialised and undifferentiated. In his study of London Church Court records Meldrum notes a similar tendency among male domestic servants themselves, who described their work with reference to much more specific occupational titles than did female servants. ${ }^{22}$ While the act recognized the variety of occupations (however superfluous) performed by male servants, the work of female servants seems almost invisible. Unlike the highly visible liveried manservant, whose finery emphasized his relative idleness and proclaimed the affluence of his employer, maidservants were generally not part of the equipage of display. The work of female servants, although integral to the maintenance of their employers' social status, was to be carried out as much as possible behind the scenes. ${ }^{23}$ Popular household manuals, such as Hannah Glasse's Servant's Directory, admonished housemaids to perform their tasks unobtrusively, with minimal disruption and noise. ${ }^{24}$ In many ways, Adam Smith's definition of unproductive labour as that which perishes in the very instance of its performance, "seldom leaving any trace or value behind," seems a particularly apt description of many of women's household chores, both paid and unpaid. ${ }^{25}$

This view of domestic service was indicative of a gradual but fundamental shift in the understanding of what constituted the economic realm of society. In this context, Smith's dismissal of domestic service as of little value because it 
did not result in a "vendible commodity" is especially telling. ${ }^{26}$ A narrowing formulation of legitimate economic activity, evident in the maidservant tax legislation, failed to recognize the work of female servants as productive. At the same time, the work of male domestics was highlighted and singled out as suspect. As with debates over "skill" in the eighteenth and nineteenth centuries, gender, more than technical abilities, often defined perceptions of economic value. ${ }^{27}$ The centrality of production in both Smithian and later Marxist characterizations of work, marginalised the labour of both male and female domestic servants. Domestic service rendered a man effeminate not only through the stigma of dependence and servility associated with the occupation, but because of the inappropriateness of his engaging in such devalued and economically worthless activity. Indeed some historians have suggested that the tax on menservants effectively discouraged the employment of men and boys in household tasks, thereby further entrenching the perception of domestic labour as woman's work. ${ }^{28}$ More recent studies have argued that there is evidence that men and boys continued to be employed in household tasks, including cleaning duties (although wishing to escape the tax, their employers stressed their association with business and agricultural duties). ${ }^{29}$ The question of the feminisation of domestic service in practice is certainly more complex than initially thought, however, in terms of concepts articulated by theorists and law-makers, domestic service was associated with the feminine. In this sense the servant tax was both a consequence of, and a contributing factor to an ideology that regarded domestic labour as economically superfluous.

A conceptual framework that identified domestic service as unproductive and effeminate was no doubt related to the alterations in the character of household labour in general over the course of the eighteenth century. Although the work of housewives and domestic servants, particularly in urban households, may have been directed increasingly towards servicing and consumption, a growing body of research has challenged the view that early industrialisation witnessed the demise of household production. Even in those prosperous homes where domestic labour no longer involved production for the market, the economic significance of that work was by no means diminished..$^{30}$ Clearly the perception of domestic labour as unproductive reflected neither the actual content of that work nor its economic worth. What this period witnessed was not so much a transformation of the economic value of domestic labour but a transformation of the terms through which that labour was understood.$^{31}$

Several key interrelated themes may be discerned from the maidservant legislation and the economic philosophy which underpinned it: a definition of domestic service and household work as unproductive, an association of productivity with masculinity, and the consequent characterization of unproductive labour as effeminate. The assumptions surrounding notions of productive labour, luxury and the appropriate roles of men and women can only be glimpsed from a reading of the legislation itself, but were much more clearly articulated in the vocif- 
erous public debate sparked by the new measure. In their response to the proposed tax, public critics contested key terms in the economic discourse shaping the government's policies and defended the value of female domestic service.

\section{IV}

The tax on menservants met with little resistance when it was first introduced in 1777. ${ }^{32}$ However, when William Pitt later attempted to extend the levy to female servants, critics of the impost accused the Prime Minister of ignoring his own criteria for the distinction between luxury and necessity, extravagance and real use. Participants in the debate on the female servant tax pointedly sought to differentiate the idleness and industry not only of servants, but of their employers as well. The maidservant tax was introduced in the same month as a new tax on retail shops, perceived as falling disproportionately upon the backs of the industrious middle classes, while the idle financier and opulent landowner escaped contributing their fair share. The two measures were frequently linked in public commentaries, viewed as a two-pronged assault on the domestic economy of the middling sort. Given the fact that employers of female servants were drawn predominantly from the middling ranks of manufacturers, retailers and widows (who may have been shopkeepers as well), this perception was well-founded. ${ }^{33}$ The tax on maidservants was particularly troubling to the middling classes of the metropolis where retailers and maidservants constituted significant sectors of the workforce. ${ }^{34}$ In London, where even the most humble of middling households would have employed one maidservant, the proportion of women working in domestic service was two to three times greater than in urban provincial centres. ${ }^{35}$ Peter Earle's analysis of early eighteenth-century London highlights the predominance of maidservants in middle-class households, with females representing 80 percent of domestic servants employed by the metropolitan bourgeoisie. ${ }^{36}$ Members of Parliament representing the City and Middlesex, whose broad electorates encompassed middling tradesmen, retailers and small freeholders, were especially outspoken against both the shop tax and the maidservants tax. ${ }^{37}$

In the press, in parliamentary speeches, and in slogans daubed on shop windows, the shopkeeper and the maidservant emerge as the embodiment of the nation's “industrious subjects, who labour under burthens already almost too heavy to be borne." ${ }^{38}$ One satirical print from the summer of 1785 depicts a shopkeeper and a maidservant hounded by a pack of ministerial curs, the shopkeeper running headlong in the direction of "Poverty," while the female domestic is chased downhill to "Prostitution" as Treasury officials harass her and her mop. The young Pitt straddles a female figure, a representation of both abused domestic servants and Britannia (a Union Jack shield has fallen under her). As Pitt hauls her about by her hair, she laments, "Thus the stubborn Youth goads me to the Heart, Himself, as yet, unconscious of the Smart." The shopkeeper too mutters about Pitt's inexperience: “The Boy knows as little of Trade as he does of Maids 


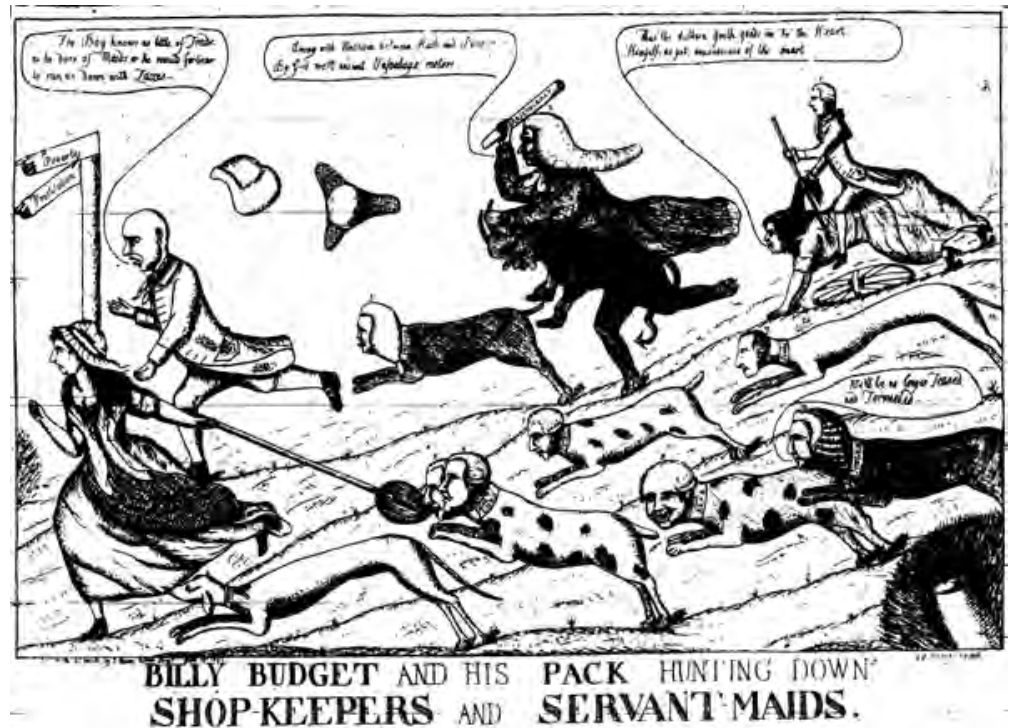

(c)British Library Board. All Rights Reserved. Humanities Mic.B.78 - Reel 9

or he would forbear to run us down with Taxes." ${ }^{39}$ Opponents of the shop tax cited it as yet another example of the young prime minister's ignorance of the practicalities of commerce. William Mainwaring, MP for Middlesex, asserted that Pitt would never have introduced such measures "if his habits of life had not rendered him wholly a stranger to shopkeepers and the nature of their business," while Alderman Watkin Lewes accused Pitt of relying solely "upon speculative ideas, though contradicted by the uniform testimony of the traders." ${ }^{40}$ The contrast between abstract theory and lived experience of work and household would be a recurrent theme in protests against Pitt's taxation package.

Servants, both male and female, figured in the controversy as items as expenditure, but also as labourers. The identification of certain forms of domestic service as productive (or not) was central to determining whether domestic servants constituted necessities or luxuries. In appeals against assessments for the manservant tax, the actual work carried out by male servants, in particular the balance of domestic and business-related tasks, was the deciding factor in the commissioners' deliberations. ${ }^{41}$ By defining servants on the basis of what they actually did (rather than residency or contract) the tax laws opened up the possibility of challenging definitions of domestic labour on the basis of actual work experience and household management practices, allowing for a popular redefinition of work and productivity. Thus, in resistance to the tax legislation (whether in appeals, or in the public protests considered here) debate became focussed on the actual labour of domestic servants. 
Female servants, opponents of the tax argued, could not be construed as objects of conspicuous consumption. Unlike the powdered and liveried menservants employed by the aristocracy and urban gentry, female servants were not luxuries but were essential to the management of the homes of the middle classes. ${ }^{42}$ In the Commons debate on the female servants tax, Charles James Fox claimed that one could not find "any set of men who were more useless subjects in a state than menservants, but the contrary was the fact with regard to female servants." Whereas menservants were kept for "parade and as the instruments of vanity, idleness and ostentation," female servants "were always employed in works of industry and management." ${ }^{43}$ Female servants, it was explained, were frequently employed by large families to care for the children; indeed many were not employees in the strict sense of the term, but were often impoverished kin, or girls sent by local charities and taken in and provided with room and board. ${ }^{44}$ A correspondent to the Times argued that female servants were a "staple commodity" and as such, should not be taxed..$^{45}$ The characterization of women as commodities would recur throughout the debate.

The Prime Minister was accused of unmanliness, in the sense of a lack of chivalric sentiment, in levying a tax upon a set of persons deserving of his protection, who were "more to be pitied than taxed." tax defended the country's female servants were suggestive of at least two lines of thought which ran through debates of the period on the social status and condition of women. The tax was reprobated by "persons of feeling and sentiment" who wished the maidservants had been treated "in a more gentle manner." 47 Indeed, the language employed in the defence of the female servants echoes that found in many of the sentimental novels of the time. MP Richard Courtenay, beseeched the Prime Minister to treat the "helpless, the innocent sex" with compassion, remembering "that they were persons of no property, that they were themselves defenceless, and had no protector but man." In a similar vein the Earl of Surrey spoke of the hardships encountered by women from "their hard and relentless destiny." ${ }^{48}$

Exemption from taxation, however much construed as an act of chivalrous protection and compassion, carried with it an assumption of an inferior social status and an exclusion from political power. A critic of the female servant tax based his arguments on the principle that taxes ought to fall upon those who had the greatest stake in the country (meaning the owners of landed property, stockholders and merchants). As maidservants had no stake in the country, it was unjust to tax them. ${ }^{49}$ While for some, the fact that women had no advocates in Parliament was a call for manly ministers to step forward in the cause of their defence and protection, for others it was a source of grievance. A correspondent to the Morning Chronicle made the daring claim that women would be safer if they enjoyed the privilege of voting for representatives in Parliament. ${ }^{50}$ The Times castigated the maidservants tax as fit only for those countries "where superstition 
denies souls to the women and tyranny refuses liberty to their persons." ${ }^{1}$

The dominant theme that emerges from criticisms of the maidservants tax was not, however, women's exclusion from political power, but their lack of economic autonomy. Although the opponents of the tax seemed to suggest that it was the maidservants themselves who would be forced to pay the tax, this was not a sign of confusion on their part, but rather a recognition, that ultimately, female domestics would pay the price for such a misguided policy. Pitt was accused of further contracting the already narrow range of employment options open to women, as many families who employed female servants would be forced to let them go once the tax came into force. For many women, domestic service was their only means of earning a living. ${ }^{52}$ In Parliament, the Earl of Surrey described the condition of women in service as one of "not voluntary but necessary slavery; they had no option; ... were they to be punished for what was their misfortune, not their crime?" 53 Most commentators on the female servant tax agreed that it would result in countless numbers losing their honest and industrious means of livelihood and being driven to the necessity of prostitution. A commentary in the Times entitled "The Raree Show" foretold the scene in the streets of the metropolis after the imposition of the tax. The maidservants of London

\begin{abstract}
are no longer industrious in honest avocations, but you see they perambulate the town and stand at the corners of streets ... and at the entrance to dark lanes and alleys, picking up men and picking up boys and spreading vice and idleness and disease all over the country. ${ }^{54}$
\end{abstract}

A letter to the Morning Chronicle from the "Patroness, Vice Patroness and Matrons of the extensive society of pleasure, instituted for the gratification of every passion that can amuse the human mind" expressed their gratitude to the Prime Minister for the maidservant tax, as the "number of robust and blooming girls who will be discharged when this salutary act takes place will greatly reduce the market price." 55 Once again we find a language of commodities and market supply and demand ironically deployed, in this case with reference to the expense of procuring fresh girls into the trade. The description of prostitution as a form of "illicit commerce" contrasts with the honest labour of the industrious and virtuous maid.

\title{
V
}

Many of those who commented on the restricted range of occupations open to women were especially critical of those men who had invaded the province of women by moving into trades such as staymaking, haberdashery, and mantuamaking. ${ }^{56}$ In a satirical commentary on the maidservant tax, the Times reported that the spiders of the metropolis were preparing an address of thanks to the Prime Minister for the tax about to be laid on "the sisterhood of cobweb-brushers." It 


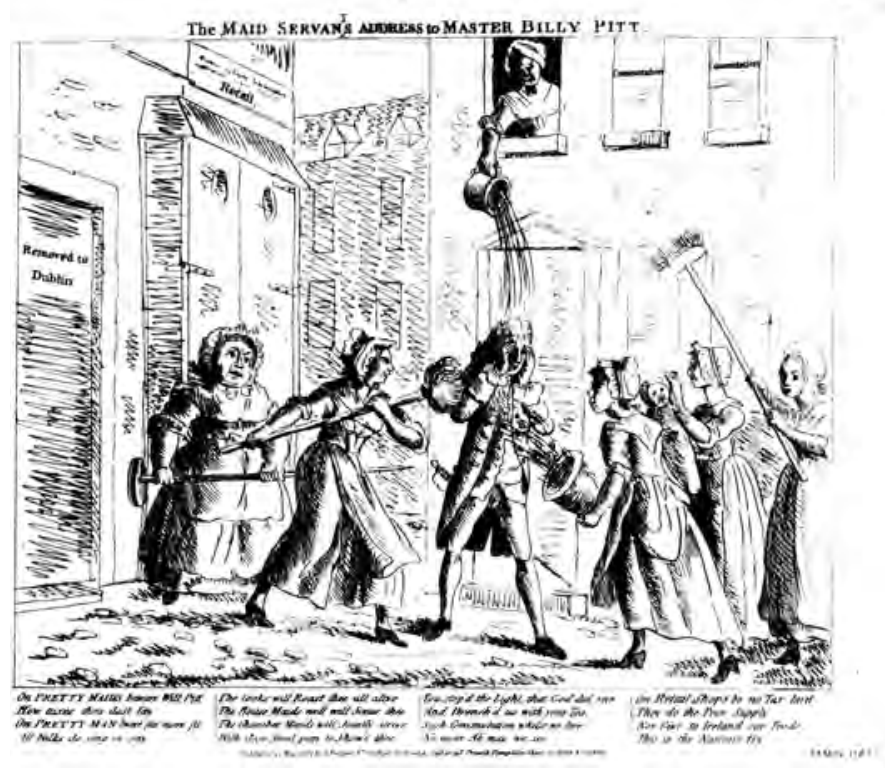

(c)British Library Board. All Rights Reserved. Humanities Mic.B.78 - Reel 9.

was further reported that "other insects, such as bugs, fleas, men-milliners, he-haberdashers, and male mantua-makers" also intended to show their gratitude for their exemption from punishment. ${ }^{57}$ Another satirical print depicts Pitt as he is assaulted with brooms and showered with the contents of chamberpots (emptied upon his head by maidservants above the shut up doors of bankrupt retail shops). The accompanying caption reads: "On Pretty Maids beware Will Pitt, How taxes thou dost lay; On Pretty Man 'twere far more fit, All folks do sing or say." ${ }^{58}$

The suggestions put forward for alternative objects of taxation reveal contemporaries' assumptions regarding the appropriate roles of men and women in the home and in the marketplace, as well as their anxieties about the moral state of society. Several MPs suggested that men who had appropriated those occupations more suited to women ought to be forced to pay a fine in the form of a licence fee. MP Brook Watson declared that instead of taxing women, "menmilliners, staymakers and every effeminate person throughout the kingdom ought to be severely taxed." ${ }^{59}$ Male mantua-makers, haberdashers and milliners were condemned not because the work itself was unproductive, but because it was women's work. What were viewed as honest, industrious occupations when appropriately carried out by women, became transformed into illegitmate and debased forms of work in the hands of men. Interestingly, there appears to be little evidence of a similar anxiety concerning the crossing of occupational gender 
barriers by women in these debates.

The use of taxation as a means of channelling persons into more appropriate and socially useful activities, implied by these alternative proposals was a strategy promoted by eighteenth-century economic theorists, particularly with regard to the labouring classes. The consumption patterns and leisure activities of the rich, though potentially damaging to the social fabric and civic virtue, were generally tolerated, so long as the state might benefit from this expenditure via taxation. Taxing the luxuries of the wealthy was advocated as a means of generating state revenue, while taxing those of the poor was promoted as an effective exercise in behaviour modification. Smith regarded moderate taxes on the luxuries of the poor, such as beer and spirits, as "the best of sumptuary laws," compelling the sober and industrious "to moderate or to refrain altogether from the use of superfluities which they can no longer easily afford." ${ }^{\circ 0}$ Similarly Steuart suggested that an increase in taxes might serve to foster habits of sobriety and application in the manufacturing classes. Steuart was particularly disturbed by what he perceived as the ruinous effects of domestic luxury among manufacturers and tradesmen, pointing to examples of manufacturers who lived luxuriously and could still afford to be idle part of the week. "Articles of ease and luxury," he asserted, "should not be left in the hands of those who are not permitted to enjoy them."

The use of taxation as an instrument of behaviour modification was to some extent implicit in Pitt's original taxation proposals, particularly as they pertained to the employment of male servants. Although servants themselves were not subject directly to taxation, it was suggested that the tax could serve to alter their behaviour for the benefit of society, forcing them to find more suitable employment, once they had been discharged by economising employers. In increasing the tax upon menservants Pitt hoped it might operate to restore to the country those persons who "in their present situation, were the least profitable of any other to the community." ${ }^{2}$ Unlike maidservants who faced the prospect of ruin if discharged, these effeminate menservants could find more productive and manly employment in the navy, army or some branch of manufacturing. ${ }^{63}$

Bachelors, another social group whose behaviour was deemed in need of regulation, were an especially favourite target for the taxman. Bachelors had been subjected to taxation in the late seventeenth century, and in the Commons the idea was brought forward again as an alternative to taxing maidservants. ${ }^{64}$ The proposal to subject bachelors to some form of levy met with widespread approval amongst the public out of doors who felt, as one correspondent to the Times expressed it, that bachelors, "by not yielding obedience to the first command of their Creator, may justly be deemed ... unprofitable members of the community." ${ }_{65}$ Bachelors were loose cannons on the ship of state who needed to be firmly grounded in the institution of marriage and transformed into useful members of civil society. The domestic ties of marriage and family would convert the dissipated, pleasure-seeking rogue to the simple virtues of hearth and home, and patriot- 
ic service to one's country. Obedience to the divine command to go forth and multiply fulfilled both one's religious and national duties. The belief that national prosperity was dependent upon a robust and expanding population was widely held in late-eighteenth century Britain. ${ }^{6}$ In a society troubled by fears of military deterioration and depopulation, bachelorhood represented a threat to national security and prosperity.

Much was made of the Pitt's own bachelor status in the debates over appropriate objects of taxation. The young Prime Minister was the butt of frequent jokes as to his seeming indifference to young ladies (it was rumoured that he went riding with a woman who was actually his sister in order to defend his character from "unmanly imputations".) ${ }^{67}$ Aspersions were cast upon his masculinity by MPs in the Commons, the press and even the streets. Retailers painted slogans on their closed shutters in protest against the shop tax; one found in Wardour Street read: "When offices are filled with silly fops, They tax your maids, Nor will they spare your shops." ${ }^{68}$ Fellow MPs recommended that he take the advice of those with greater knowledge and experience of women, and drop the tax. ${ }^{69}$ The patroness of the society of pleasure (mentioned earlier) in thanking Pitt for the boon to their business sure to result from his maidservants tax, was especially obliged as "none of us ever recollect to have had the pleasure of receiving you at any of our convivial or private parties." ${ }^{\prime 70}$ Several weeks later, a similarly satirical notice appeared in the Morning Chronicle, reporting the proceedings of a meeting of the Society of Bachelors and Fumblers. Addressing their "brother" Pitt, they advocated that those "fumblers" who had "been tried and found wanting", i.e. married men who had failed to produce children, be taxed in equal proportion to bachelors. ${ }^{71}$

The spectre of a declining population was prominent in the criticisms directed against the new tax on female servants. Taxing them would place an intolerable burden on the large families who were most in need of their services, and, it was feared, in the long run would act as a discouragement to having children. Fox declared it a "tax upon infants, and not a tax upon luxury or extravagance," while the literary wit and MP Richard Brindsley Sheridan declared it a "bounty to bachelors and a penalty upon propagation." "' Interestingly, the concern expressed here was for the reproductive choices of masters and mistresses, rather than those of the maidservants themselves, who would have forfeited their live-in positions upon marriage.

Bachelors were not the only set of persons who undermined domestic life and inhibited population growth. Prostitutes were proposed as fitting objects of taxation, as they were equally "enemies to population." 73 Farther down the scale of viciousness, although almost as detrimental to domestic virtue was the custom of sending one's children out to a wet nurse, a practice indulged in by the fashionable ladies of the bon ton. Condemned by the growing numbers of advocates of maternal breast-feeding, it was hoped that penalizing these undomesticated ladies 
by taxing their wet-nurses would discourage the practice. ${ }^{74}$ In their recommendations for alternative objects of taxation, participants in the debate over female servants articulated a number of inter-related concerns regarding the erosion of domestic life and the prospect of a diminishing population, thus suggesting that productive labour and profitability to the community had as much to do with reproducing and nurturing future citizens as it did with the increased outputs of manufactures and expanding commerce.

The association of national prosperity and an expanding population was a common theme in the works of eighteenth-century economic commentators. Although he viewed a growing population as a symptom, rather than a cause of prosperity, Smith expressed concern at the deleterious effects of luxury on both production and reproduction. He contrasted the frugal habits of the industrious poor "who generally bring up the most numerous families, and who principally supply the demand for useful labour" with the indulgent behaviour of the "dissolute and disorderly" lower classes whose children perished from neglect and mismanagement. ${ }^{75}$

Smith differentiated the consequences of luxury on the reproductive abilities of the labouring classes from its effects on the wealthy. Luxury, primarily in the form of parental overindulgence in drink, resulted in higher mortality rates amongst the children of the poor. Although labouring women might bear many children, they were unlikely to survive to become productive citizens if their families belonged to that class of "dissolute" persons described by Smith. On the other hand, a pampered, fine lady, he claimed, was often incapable of bearing any children. "Luxury in the fair sex, while it inflames perhaps the passion for enjoyment, seems always to weaken, and frequently to destroy altogether, the powers of generation. ${ }^{36}$

Steuart, who viewed depopulation as "a mark of political diseases," was similarly troubled by the unproductive procreation of the poor. He distinguished between "real multiplication" in which children are raised by parents who are capable of maintaining them and go on to "serve the state", and mere procreation. Steuart advocated a much more interventionist role for the state, asserting that it was the duty of a statesman to ensure the "real multiplication" of the labouring classes. He proposed a scheme whereby the state would monitor the fertility of the various classes in society and regulate their patterns of marriage and propagation. Governments which wished to turn the operations of the modern economy to the best advantage of their citizens could not afford to neglect the state of their nations' population. ${ }^{77}$

The concerns expressed by Enlightenment economists regarding the consequences of a declining population offer insight into contemporary understandings of the relationship between reproductive labour and the wealth of nations. Women may have been construed as participating only marginally in what was defined as economic activity, yet their reproductive labour in creating, nurtur- 
ing and training future generations of industrious labourers was recognized as essential to economic prosperity, although it was rarely defined as a form of productive labour. This aspect of women's household labour, if largely unacknowledged by economic theorists and government legislators did receive some recognition from the public in their response to the female servant tax. Repeatedly commentators on the tax insisted that female servants were essential to the rearing of large families - their household labour was an industrious and productive form of work.

Pitt's amendments to his initial taxation proposals may be better understood in the context of these wider concerns about domestic virtues, depopulation and the supply of labour. Abatements on the female servants tax were granted for large families, and, despite the ribald tone of much of the press commentary on the virtues and vices of bachelorhood, an amendment to the legislation was introduced which would charge all bachelors over the age of 21 an additional $£^{1-5 s}$. for each male servant in their employ, thus penalizing two species of unproductive men at a single stroke. ${ }^{78}$ The columns of the metropolitan papers applauded the new tax; the Times reported that "every tea-table rings with the praise of the new duty as a stimulus to matrimony." In a later commentary the paper asserted that the tax on bachelors would "so enhance the worth of unmarried ladies, that like other commodities they will rise in value, on account of the great demand that must ensue." The rising value of virtuous unmarried women would come at the expense of the value of "the frail sisterhood" (a euphemism for prostitutes) who, the paper claimed were alarmed at the prospect of a fall in the value of their own commodities. $^{79}$ Once again we find a commercial language of merchandise and markets employed with regard to women in these comments, which, however mocking and satirical in tone, is worthy of consideration, as the commodification analogy is not as prominent in discussions in the value of men in these debates.

\section{VI}

The anxieties expressed about the consequences of a declining population were exacerbated by the loss of America and a general feeling that Britain had passed the apogee of its imperial fortunes. In Parliament the Earl of Surrey asserted that

\footnotetext{
it was a strong proof of the declension of an empire, to be raising a revenue from taxing the necessaries of life, and at the same time to be afraid to touch our pleasures and the dissipations of the times. ${ }^{80}$
}

This line of attack rubbed salt into the wounds of a nation still smarting from its humiliating defeat at the hands of the rebellious American colonists. It was a common theme in commentaries on the war with America that the loss of so extensive an empire must surely be a divine visitation upon a society so preoccupied with the pursuit of private pleasures and consumer luxuries as to be incapable of 
dedicating itself to public virtue. ${ }^{81}$

The public soul-searching which manifested itself after the war with America resulted in numerous variations on the theme of "Reform or Ruin!", one of which was that extravagance and luxury (which often shaded into vice) ought to be actively discouraged, or at least made to benefit the state, through punitive taxation. Writing to the Morning Chronicle, the well-known metropolitan social reformer Josiah Dornford argued that female servants ought not to be subject to taxation "while so many luxuries, extravagances, vices and follies of the present day remain untouched." Taxes, he suggested

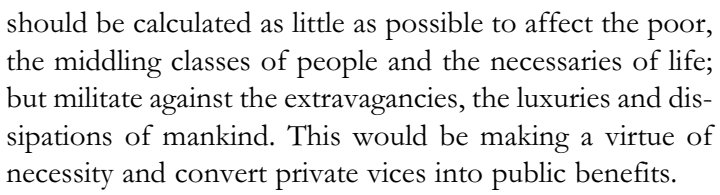

Included in the list of alternative objects of taxation which would yield a sufficient revenue for the Treasury at the same time as curbing the vicious habits of the populace were sporting dogs, houses of dissipation, tavern bills over 40s., cards and dice, opera tickets, and that perennial favourite, attorneys. ${ }^{82}$ Thus the debate over appropriate objects of taxation disclosed a cluster of apprehensions centring on the loss of empire-commercial decline, depopulation, and national degeneration brought about by unchecked luxury, viciousness and effeminacy. By penalizing unproductive and effeminate menservants, and encouraging their enlistment in the armed forces, it was hoped that the disease that appeared to be enervating the nation's manhood and martial spirit could be checked. Recognition of service to one's country was also held out by a clause in the new legislation which exempted naval and army officers, including those wounded in his Majesty's Service, from payment of the tax. ${ }^{83}$ Viewed from this perspective, the new taxation proposals fit into an overall programme to revive Britain's imperial fortunes.

\section{Conclusion}

The outcry against the female servant tax was such that despite the modifications allowing reductions for families with numerous young children, the government was forced to repeal it in $1792 .{ }^{84}$ The tax on male servants however, continued to generate income for the Treasury for another century. ${ }^{85}$ The debate over the female servant tax, as this essay has attempted to demonstrate, was caught up in a much wider set of issues which preoccupied contemporaries in late-eighteenth century Britain. A taxation policy which targeted luxury items (however elastic the definition) continued to be pursued by governments anxious to avoid direct taxes on income. In their reasoning, taxes on luxury fostered a number of civic goals apart from paying down the national debt: channelling men into the armed servic- 
es, stemming vice and disease, and shoring up the defenses of empire.

Opponents of the maidservant tax responded in kind, pointing out the potentially disastrous consequences, not just for the households of the industrious middling sort, but also for the nation. In the proposals for alternative objects of taxation-prostitutes, places of public entertainment, gambling, foppish and unmanly forms of behaviour and occupation, bachelors - we can pinpoint the features of society which contemporaries believed threatened a just and virtuous social order. Their apprehensions for the moral state of the country were further heightened by the spectre of imperial decline and national degeneration. The ideal that critics of the female servants tax held forth in these debates was one in which women and men maintained themselves and their families through honest and productive labour. The rewards of industry would not be dissipated at the public house, brothel or gaming table, but would be devoted to the maintenance of a growing family. In the bosom of domesticity, the next generation of citizens would be nurtured and educated for a life of public virtue, usefulness to the community, and national service. The female servant tax, in the eyes of its critics, threatened to undermine this imperial mission-it sapped the strength of the nation by penalizing and ultimately discouraging large families, it eroded domestic life (the surest source of a virtuous citizenry), it deteriorated the moral and physical health of the country's inhabitants by encouraging prostitution, and it failed to check the debilitating and enervating effects of effeminacy and luxury.

Those addressing the concerns raised by the imposition of the maidservant tax drew on a language of political economy articulated by Enlightenment economists. However, a careful reading of the controversy reveals that this language, while shared, was far from stable. Key terms within this economic vocabulary such as industry, luxury and productive labour were open to multiple meanings in different contexts. Legislators defined luxury in such a way as to extend the reach of consumption taxes farther down the social scale to include the employers of maidservants. What was construed as an attempt to exclude female domestic service from the honourable class of industrious and productive labour elicited a public response that resisted definitions of household work as unproductive and acknowledged the labour of female servants in the rearing of large families. The condemnation of bachelors that erupted during the controversy is likewise suggestive of a broader understanding of the concept of productivity in an era when an expanding population was as significant an indicator of economic wellbeing as rising export figures.

\section{Notes}

1. Accounts of domestic service in eighteenth-century Britain include Bridget Hill, Servants: English Domestics in the Eighteenth Century (Oxford: Clarendon Press, 1996); Tim Meldrum, Domestic Service and Gender, 1660-1750 (Harlow: Pearson Education, 2000); Peter Earle, "The female labour market in London in the late seventeenth and early eighteenth centuries," 
Economic History Review 42, no. 3 (1989): 328-353, and his A City Full of People: Men and Women of London, 1650-1750 (London: Methuen, 1994); D.A. Kent, "Ubiquitous but Invisible: Female Domestic Servants in Mid-Eighteenth Century London," History Workshop Journal 28 (1989): 111-128; Dorothy Marshall, The English Domestic Servant in History (London: Historical Association, 1949); J. Jean Hecht, The Domestic Servant Class in Eighteenth-Century England (London: Routledge and Kegan Paul, 1956). Ann Kussmaul, Servants in Husbandry in Early Modern England (Cambridge: Cambridge University Press, 1981) is the classic account of rural service-in-husbandry. Douglas Hay and Paul Craven, eds., Masters, Servants and Magistrates in Britain and the Empire, 1562-1955 (Chapel Hill: University of North Carolina Press, 2004) is itself a masterful study of global scope which investigates the relationship between the law of master and servant and the consolidation of empire.

2. See Marjorie Cohen, "The Problem of Studying 'Economic Man'," in Feminism: From Pressure to Politics, eds. Angela Miles and Geraldine Finn (Montreal: Black Rose Books, 1989), 148-159; Marianne A. Ferber and Julie A. Nelson, eds., Beyond Economic Man: Feminist Theory and Economics (Chicago: University of Chicago Press, 1993); Nancy Folbre and Heidi Hartmann, "The rhetoric of self interest: Ideology of gender in economic theory," in The Consequences of Economic Rhetoric, eds. A. Klamer, D.N. McCloskey and R.M. Solow (Cambridge: Cambridge University Press, 1988), 184-203; Julie A. Nelson, "Gender, Metaphor and the Definition of Economics," Economics and Philosophy 8 (1992): 103-125; Anne Phillips and Barbara Taylor, "Sex and Skill: Notes towards a Feminist Economics," Feminist Review 6 (1980): 79-88; Marilyn Waring, If Women Counted: A New Feminist Economics (San Francisco: Harper, 1988).

3. Joan Wallach Scott, “L'ouvrière! Mot impie, sordide...': Women Workers in the Discourse of French Political Economy, 1840-1860," in Gender and the Politics of History (New York: Columbia University Press, 1988), 139-163; Jane Rendall, "Virtue and Commerce: Women in the Making of Adam Smith's Political Economy," in Women in Western Political Philosophy, ed. Ellen Kennedy and Susan Mendus (New York: St. Martin's Press, 1987), 4477; Michael Roberts, “Words they are women and deeds they are men': images of work and gender in early modern England," in Women and Work in Pre-Industrial England, eds. L. Charles and L. Duffin (London: Croom Helm, 1985); see also Michele A. Pujol, Feminism and Anti-Feminism in Early Economic Thought (New York: Gower Press, 1992).

4. Less than 20 percent of government income derived from the land tax and other direct taxes on wealth. Peter Mathias, "The Finances of Freedom: British and American Public Finance during the War of Independence," in The Transformation of England (London: Methuen, 1979), 287-288.

5. 25 George III c.43. An Act to repeal the Duties on Male Servants; and for granting new Duties on Male and Female Servants. The tax on menservants had been in effect since 1777. 17 George III c.39. An Act granting His Majesty a Duty upon all servants and for repealing duties on glass and silver. Stephen Dowell, A History of Taxation and Taxes in England, Vol. 3 (London: Frank Cass, 1965), 215-225; J.E.D. Binney, British Public Finance and Administration, 1774-92 (Oxford: Clarendon Press, 1958), 68-69. See also William Kennedy, English Taxation, 1640-1799 (1913, repr., London: Frank Cass, 1964).

6. The Parliamentary Register, ed., J. Debrett, (London), 18 (1785): 213.

7. Malcolm Jack, Corruption and Progress: the Eighteenth-Century Debate (New York: AMS Press, 1989); J. G. A. Pocock, Virtue, Commerce and History (Cambridge: Cambridge University Press, 1985); John Sekora, Luxury: the Concept in Western Thought, Eden to Smollett (Baltimore: 
Johns Hopkins University Press, 1977); Christopher Berry, The Idea of Luxury: A Conceptual and Historical Investigation (Cambridge: Cambridge University Press, 1994). For considerations of the cultural and consumer experience of luxury see Consumption and the World of Goods, eds. John Brewer and Roy Porter (London: Routledge, 1993); Consumers and Luxury: Consumer Culture in Europe, 1650-1850, eds. Maxine Berg and Helen Clifford (Manchester: Manchester University Press, 1999); John Brewer, The Pleasures of the Imagination (London: Harper Collins, 1997); Maxine Berg and Elizabeth Eger, eds., Luxury in the Eighteenth Century: Debates, Desires and Delectable Goods (New York: Palgrave Macmillan, 2003); Maxine Berg, Luxury and Pleasure in Eighteenth-Century Britain (Oxford: Oxford University Press, 2005).

8. David Hume, "Of Refinement in the Arts," in Essays Moral, Political and Literary, ed. Eugene F. Miller (1777; Indianapolis: Liberty Classics, 1987), 268.

9. Adam Ferguson, An Essay on the History of Civil Society, ed. Duncan Forbes, (1767; Edinburgh: Edinburgh University Press, 1966), 142; Adam Smith, An Inquiry into the Nature and Causes of the Wealth of Nations, Vol.2, eds. R.H. Campbell and A.S. Skinner (1776; Oxford: Oxford University Press, 1976),870.

10. Hume, "Of Refinement in the Arts," 269; Sir James Steuart, An Inquiry into the Principles of Political Oeconomy, Vol.1, ed. A.S. Skinner, (1767; Edinburgh: Oliver and Boyd, 1966), 266-69.

11. Steuart, Principles of Political Oeconomy, 265.

12. Smith, Wealth of Nations, 2: 848, 853.

13. Smith, Wealth of Nations, 2: 871-73; Steuart, Principles of Political Oeconomy, 2: 683-84, 697.

14. John Ehrman, The Younger Pitt, vol. 1 (London: Constable, 1969), 132, 267 n.1.

15. Susan E. Brown, “'A Just and Profitable Commerce': Moral Economy and the Middle Classes in Eighteenth-Century London," Journal of British Studies 32 (1993), 319-320.

16. Smith, Wealth of Nations, 1: 330 .

17. For discussion of the moral distinction between "productive" and "unproductive" labour in the popular understanding of political economy see Gregory Claeys, "The Reaction to Political Radicalism and the Popularisation of Political Economy in Early Nineteenth-Century Britain," in Expository Science: Forms and Functions of Popularisation, eds. Terry Shinn and Richard Whitley (Lancaster: D. Reidel, 1985), 119-136.

18. Smith, Wealth of Nations, 1: 336.

19. Smith, Wealth of Nations, 1: 337-38, 348-49.

20. See Deborah Valenze, The First Industrial Woman (New York: Oxford University Press, 1995).

21. Carolyn Steedman, "The servant's labour: the business of life, England, 1760-1820," Social History 29, no. 1 (2004): 1-29.

22. Meldrum, 131-132.

23. On the domestic servant hierarchy see Leonore Davidoff, "Mastered for life: Servant and wife in Victorian and Edwardian England," Journal of Social History 7 (1974): 406-425; see also Marshall and Hecht.

24. Hannah Glasse, The Servant's Directory, or Housekeeper's Companion (London, 1760), 23.

25. Smith, Wealth of Nations, vol.1, 330. See Nancy Folbre, "The Unproductive Housewife: Her Evolution in Nineteenth-Century Economic Thought," Signs 16 (1991): 463-484, for an analysis of the role played by political economists and statisticians in representing housewives as unproductive workers

26. Smith, Wealth of Nations, vol. 2, 675.

27. Maxine Berg, The Age of Manufactures (London: Fontana, 1985); Sonya O. Rose, Limited 
Livelihoods. Gender and Class in Nineteenth Century England (London: Routledge, 1992).

28. Caroline Davidson, A Woman's Work is Never Done: A History of Housework in the British Isles 1650-1950 (London: Chatto \& Windus 1982), 180-181. Davidson's examination of the 1781 casebook of appeals of the commissioners of excise indicates that male apprentices and farm labourers who performed domestic tasks on a part-time basis were considered liable for the tax. On the feminisation of domestic service in the nineteenth century see Theresa M. McBride, The Domestic Revolution (London: Croom Helm, 1976).

29. Steedman, 18-27.

30. On the changing character of housework and domestic service in the eighteenth and nineteenth centuries see Bridget Hill, Women, Work and Sexual Politics in Eighteenth-Century England (Oxford: Basil Blackwell, 1989) and Leonore Davidoff, "The rationalization of housework" in Dependence and Exploitation in Work and Marriage, ed. Diana L. Barker and Sheila Allan (London: Longman, 1976), 121-151. Scholarly debates on the political economy of housework, although concerned with unpaid domestic labour, are relevant here in so far as they offer insight into the development of conceptual categories shaping the understanding of work in the past and present. See Wally Seccombe, "The housewife and her labour under capitalism," New Left Review 83 (1974): 3-24; Jean Gardiner, "Women's domestic labour," New Left Review 89 (1975): 47-58; Terry Fee, "Domestic labour: An analysis of housework and its relation to the production process," Review of Radical Political Economics 8 (1976):1-8; Nona Glazer, "Housework," Signs 1 (1976): 905-922; Glazer, "Servants to Capital: Unpaid domestic labour and paid work," Review of Radical Political Economics 16 (1984): 61-87; Jeanne Boydston, Home and Work: housework, wages, and the ideology of labor in the early republic (Oxford: Oxford University Press, 1990); Joanna Bourke, Husbandry to Housewifery: Women, Economic Change and Housework in Ireland, 1890-1914 (Oxford: Oxford University Press, 1993).

31. Any analysis of the changing meaning of domestic labour must be careful not to conflate the unpaid labour performed by housewives and female kin with the waged work of domestic servants. Obviously both entail different (but at times overlapping) sets of social and economic relations. Although this essay centers on a debate over domestic service, the economic discourse shaping this controversy had significant implications for the value accorded to both waged and unwaged domestic labour.

32. Parliamentary Register 6 (1777): 185-186, 238-239.

33. On middle class employment of female domestic servants see Peter Earle, A City Full of People (London: Methuen, 1994), 274-6 and his The Making of the English Middle Class (London: Methuen, 1989), ch.8; Kent, 119 and Meldrum, 22-23.

34. L.D. Schwarz estimates that shopkeepers made up 11-14 percent of London's employed population. See L.D. Schwarz, London in the Age of Industrialisation (Cambridge: Cambridge University Press, 1992), 29.

35. Schwarz, London, 17.

36. Earle, Making of the English Middle Class, 218-219.

37. For analyses of the electoral sociology of the metropolis and the growth of a "middling voice" in national politics see George Rudé. Wilkes and Liberty (Oxford: Clarendon Press, 1962) and Nicholas Rogers, Whigs and Cities (Oxford: Clarendon Press, 1989).

38. Morning Chronicle (London) 21 May, 1785.

39. M. Dorothy George, Catalogue of Political and Personal Satires Preserved in the Department of Prints and Drawings in the British Museum (London: British Museum, 1938) vol. 6, no. 6797. 
40 The Times (London) 14 June, 1785; The Parliamentary History of England, ed. William Cobbett (London, 1806-20), 25: 781; Parliamentary Register, 22 (1787): 183.

41. Steedman, 19-22.

42. Schwarz notes that contemporaries tended to exaggerate the numbers of menservants employed (particularly by the upwardly mobile middle classes), viewing them as proof of the excessive consumerism and luxury which threatened the nation's moral fibre. See Leonard Schwarz, "English Servants and their Employers during the Eighteenth and Nineteenth Centuries," Economic History Review, New Series, 52, no. 2 (1999): 236-38, 253.

43. Parliamentary History, 25 (1785/86): 569.

44. Meldrum suggests that kin may have been more useful in identifying work opportunities, rather than as employers themselves, 30. But see also Naomi Tadmor, Family and Friends in Eighteenth CenturyEngland: Household, Kinship and Patronage (Cambridge: Cambridge University Press, 2001) which highlights the flexible and permeable framework of the "household-family" and suggests that some members of the household fulfilled multiple roles: e.g., relatives, boarders and servants.

45. Times, 11 May, 1785.

46. Parliamentary Register 18 (1785): 223.

47. Parliamentary History 25 (1785/86): 562; Parliamentary Register 18 (1785): 222.

48. Parliamentary Register 18 (1785): 490, 221.

49. Morning Chronicle 18 May, 1785.

50. Morning Chronicle 5 July, 1785.

51. Times 17 May, 1785. The image of Turkish despotism alluded to here was a device used both by those who wished to condemn the condition of women in England, as well as those who sought to compare it favourably with other "barbarous and superstitious" countriesthe sense in which it is being used here is ambiguous.

52. On the relatively narrow range of women's occupations, even in the earlier part of the century, see Earle, "The Female Labour Market in London in the Late Seventeenth and Early Eighteenth Centuries," Economic History Review, New Series, 42, no. 3 (1989): 328-353. 53. Parliamentary History 25 (1785/86): 558.

54. Times 13 May, 1785.

55. Morning Chronicle 12 May, 1785.

56. The fact that staymaking, a largely male occupation, was construed as a female occupation which had been appropriated by men, suggests a contested and perhaps increasingly rigid understanding of the sexual division of labour during this period. On stay-making as a male occupation see R. Campbell, The London Tradesman (London, 1757), 224-226.

57. Times 12 May, 1785.

58. George, cat. no. 6794.

59. Parliamentary History 25 (1785/86): 575.

60. Smith, Wealth of Nations, 2: 871, note 5; 872.

61. Steuart, Principles of Political Oeconomy, 2: 692, 691, 685.

62. Parliamentary Register 18 (1785): 213.

63. The relationship between masculinity and work identities is explored by Keith McClelland, "Some thoughts on masculinity and the 'representative artisan' in Britain, 18501880," Gender and History 1 (1989): 164-177, and Rose. See also the collection of essays edited by Michael Roper and John Tosh, Manful Assertions: Masculinities in Britain since 1800 (London: Routledge, 1991). 
64. The tax on bachelors was in place from 1695-1706, Dowell, 2: 46.

65. Times 10 June, 1785.

66. D.V. Glass, Numbering the People: the eighteenth-century population controversy and the development of census and vital statistics in Britain (Farnborough: D.C. Heath, 1973).

67. Times 18 June, 1785.

68. Morning Chronicle 15, 16 June 1785; Times 15, 16 June, 1785.

69. Parliamentary Register 18 (1785): 489.

70. Morning Chronicle 12 May, 1785.

71. Morning Chronicle 4 June, 1785.

72. Parliamentary History 25 (1785/86): 557, 563.

73. Times, 2 June, 1785.

74. Parliamentary History 25 (1785/86): 562.

75. Smith, Wealth of Nations, 2: 872.

76. Smith, Wealth of Nations, 1: 97.

77. Steuart, Principles of Political Oeconomy, 1: 75-80.

78. Parliamentary Register, 18 (1785): 484; 25 George III c. 43. Bachelors were also charged a higher rate for the female servants they employed -5 s. each for two maidservants and 10s. for three or more.

79. Times 18 May, 2, 17 June, 1785.

80. Parliamentary Register 18 (1785): 239.

81. See Michael Ignatieff, "John Millar and Individualism," in Wealth and Virtue: The Shaping of Political Economy in the Scottish Enlightenment, ed. Istvan Hont and Michael Ignatieff (Cambridge: Cambridge University Press, 1983), 334.

82. Morning Chronicle 26 May, 1785.

83. 25 George III c.43. Exemption was granted for up to one male servant.

84. The government was more open to repeal given the relatively small returns for such an unpopular tax. The female servant tax brought in on average $£ 31,000$ per annum in the years it was collected. PRO T1/700/49-50. "An Account of the net produce of the duties upon female servants for 4 years ending 5 April 1791."

85. Dowell 3: 215-223. 